\title{
(2) Ecological and Economic Dissonance Debate on aße Kilimanjaro Region: Reflecting on 2-Basic Questions Case to Establish E1/E2
}

\author{
Msaki Juda Leonard ${ }^{1}$, Kelvin Mwita ${ }^{2}$, Cesilia Ruoja ${ }^{3}$ \\ ${ }^{1}$ Lecturer, Finance and Economics, Moshi Cooperative University, P.O BOX 474 Moshi, TANZANIA \\ ${ }^{2}$ Lecturer, Management, Moshi Cooperative University, P.O BOX 474 Moshi, TANZANIA \\ ${ }^{3}$ Assistant Lecturer, Procurement Management, Moshi Cooperative University, P.O BOX 474 Moshi, TANZANIA \\ E-mail for correspondence: minajuda@yahoo.com \\ Cell Phone: +255 767827896 \\ Received: Jun 08, 2015; $\quad$ Accepted: Jun 21, 2015; \\ Published: Jul 21, 2015 \\ Source of Support: Nil \\ No Conflict of Interest: Declared
}

\begin{abstract}
Studying an interaction between more than one variable, both in influence and action is never an easy task, but establishing a key functional observation and question is even extremely difficult to an academician. The current literature therefore tries to re-establish an empirical debate between bi-polar ends, taking the influence of human destructive-constructive ends on both variables ecosystem (E1) and economic needs (E2).

Kilimanjaro has been taken to represent a case in Tanzania reflecting African 4 - zones on economic agriculture, as it represents among sectors of economy, 47 percent of GDP and employs 85 percent of Tanzanian population. The current literature refers to Global perspective as Global warming covers not only Africa but the whole world reforms platforms.

Institutional suggestions therefore cover solutions in terms of theoretical and empirical reflections for both. Where economic parameters and statistical dimensions cover the most dynamic era of plans, actions and the way forward (1990s -2000s). The evils of poverty has been linked to the impacts of unbalanced Dr. Msaki's ratio (GE1/GE2 $=r^{\circ}$ ), where question A and B articulate further platforms for future researched. The literature concludes by re-establishing an implementation cycle of root I and II focused on balancing criterion of $\mathrm{r}^{\circ}$ - establishment in terms of culture, strategies, focus and policies.
\end{abstract}

Keywords: Ecosystem, deforestation, biodiversity, economic aggregates, GFCF, GDP, ecology, GE1, GE2, $\mathrm{r}^{\circ}, \mathrm{O} 2$, population density, par capital, bi-polar, deforestation, utility

JEL Classifications Code: E6

\section{CONCEPTUAL INTRODUCTION: SPREAD OF EConomic VALUe and EnVIRonmental Contents}

When an investor lends money to the borrower, the borrower must pay back the money originally borrowed and also the fee charged for the use of money called "interest"... we are the negative and positive investors in the past, present and the future if mother earth. How much should be the "interest" to be paid back to the earth? We keep on investing in "development"... who should evaluate the means and ways, amount to be paid back to the mother earth? (the owner of development resources we keep on borrowing?) in the principles of finance, one can remember what is known as the "Merchant rule"..." the entire debt and each partial payment earn interest to the final settlement date. The balance due on the final date is simply the difference between the accumulated values of the debt and accumulated values of the partial payment..."can this apply to the measurement of what should be the concept known as sustainable development? What should be a redemption date? Can the real value of the environment be known? What is the essential value of oxygen? The gas (O2) which support our presence the whole life? Knowledge can develop, spread and utilized through open discussion and criticism where academic debate in theories becomes an essential part of the present literature. (Public sphere)...Much of constructed problems in human life are due to unbalanced contrast between social systems and environmental-life would...taking for granted the systems around us has costed the lives of millions in the world, by considering fundamentals of surviving and economics of our requirements (needs vis-à-vis necessity vis-à-vis greedy).

One cannot ignore the dimensions of scientific knowledge between environmental value and developmental value, 
which brings about the core philosophy of the present literature, without ignoring the philosophy need... "Philosophy of consciousness". How then can we finetune between survival needs-extrally extended, which harms environmental value?

\section{Methodology}

Establishment of a measurement through Ratio $\left(r^{\circ}\right)$ in the context of economic and ecological enrichment based on social-economic behavior across national and International contexts. Discussion was focused on 2-basic questions Case... as premises setting.

\section{ENVIRONMENT: SUBSTANTIAL RATIONALITY VIS-À- VIS FunCTIONAL RATIONALITY}

From functionality of surviving mechanism one can question: what comes first at the huge perspective? Development or environment? Where and how should we extend economic theory and rationality within the framework of cost- "opportunity cost"... choosing the best alternative ... what should be our means to evaluate the best choice? The surface of the answer needs much of debatable considerations.

Environment doesn't mean to be taken as exposure to survive means a mere exposure. Zajonc (1968) defined mere exposure being the tendency to develop more we exposed to them... No more action or interaction with the object is required, and we do not need to possess or even develop any explicit belief about object

Discussing on interactive systems becomes very difficult due to dynamics in elements and subsystems: economic development and environment are major systems, leave alone strategies and policies.

The interphases to be considered are: environmental, social and political sets. Thinking of normal historical data: Ethiopia agriculture sector amounts employment about 40 percent of GDP, 90 percent of exports, 85 percent of employment, 90 percent of the "poor" depend on agriculture... Ethiopia is well experienced in famine and its risk..why? "The colour of life is not the colour of possessions, but dignity carries the colour of all"... (Msaki J.L 2011) Great days therefore of the person need an achievement of multiple decisions, made to cover the day positively.

Tanzania and the world lives in the world that is intensively worrying, promises and marketed rapid changes, deep conflicts tensions and social divisions...increasing concerns about the destructive impact of human societies on the environment. One should think which direction will societies take in the future? Even in lush rainforest, where water is abundant, urban settlement intensive practices, factories can make access to clean water difficult task ( Millenium Development Goal-set by United Nations in 2000, is to reduce by half the portion of people without access to safe drinking water. During 1990's, nearly 1 billion people gained access to safe water and the same number of sanitation, though ensuring safe water supplies remains a problem, particularly in some parts of Africa (UNDP, 2002). The means to attain economic and social gains, without destructive efforts on environmental factors, stands to be a critical affair of the present literature.

According to Richard Wachman, Obsever (2007), the Palestine-Israel conflict is at least partly about securing supplies from the river Jordan; similarly water is a major feature of the strife in Sudan that has left Darfur devastated. When it comes to this, most basic commodities, the stakeholders could hardly be higher. According www.globaleducationproject.org/earth/humanconditions.php (accessed Jan, 2008), 18-32 percent of Tanzanian population lack access to safe water... think on the economic drives vis-à-vis environmental drives on such problem... should Tanzania privatize water resources? The hypothesis being: if water sources are privatized in Tanzania, water supplies will lead to higher cost, which in turn will help to stop (prevent) people from wasting water unnecessarily and therefore, indirectly to water conservation... The conflict of rationalities may arise from, substantial rationality vis-à-vis functional rationality... how should we balance on this? There are a lot to be re-considered, for example forests are essential part of ecosystem, destruction of forested land usually through commercial logging is what we call deforestation. According to Anthon, G (2009:171), "deforestation claimed 15 million hectares of land in the 1980's, with the largest amounts occurring in Latin America and Caribbean, losing 7.4 million hectares and Sub-Saharan Africa, losing 4.1 million hectares"... what happens to biodiversity? Environment? Surviving concept?

Deforestation has both human and environmental costs...consider the livelihood mechanism while deforestation being considered as a means to attain economic gains...where is the rationality? 830 million people around the globe go hungry each day and soil degradation threatens to undermine economic development and growth in Africa... think on global warming, is it a myth or reality? (which may contribute to heavy desertification and poor harvest, back to food shortage...who supports the harmony? Who supports the food volume to the growing population in Africa? According to NewScientist (2003 october) scientists have estimated that the numbers of dying from the side-effects of climate change, such as malaria and malnutrition, could almost double by 2020 (ibid, $1^{\text {st }}$ October 2003). Global warming is regarded by many people to be the most serious environmental challenge of our time.

A person in Tanzania needs to think critically as agriculture contributes to 47 percent of GDP and employs 85 percent of population... if Global warming takes the change seriously, then it has the potential to other irreversibly the functioning of the Earth's climate and produce a series of devastating environmental consequences which will not only affect Tanzania but the whole world...think on Geopolitical instability, what is the influence between environment and economic attitude? 
Tanzania keeps on re-considering a balanced nature between the economic drive, development and economic attitude and global picture rationality. (Millennium Goals 2000 vis-à-vis vision 2025) ... Think on the mining economics...in Tanzania's land and environmental challenges, political stability challenges...who should decide what to do with the mines? Environment? Becomes a millennium challenge for Tanzanians to balance between economic substitutes (mining sector for example) in terms of main economic aggregates of mining sector and the vision and demands from the world economics... where is the environment?

For an economist is quite simple to measure where economically direct the benefits of mining at local and national level. Consider Tanzania economic aggregates from 1996 - 2000 in table 1.

Table 1: Millennium Economic Value from Ecological Utility and Resources' Dynamics Estimates

\begin{tabular}{|c|l|c|c|c|c|c|}
\hline S/N & $\begin{array}{l}\text { Economic } \\
\text { aggregates }\end{array}$ & 1996 & 1997 & 1998 & 1999 & 2000 \\
\hline 1 & $\begin{array}{l}\text { Value added at current } \\
\text { factor (Mill Tsh) }\end{array}$ & 38,511 & 53,515 & 74,386 & 85,792 & 99,519 \\
\hline 2 & Real Growth Rate (\%) & 9.7 & 17.1 & 27.1 & 9.1 & 13.9 \\
\hline 3 & Share if mining in GDP (\%) & 1.5 & 1.7 & 2.0 & 2.1 & 2.3 \\
\hline 4 & $\begin{array}{l}\text { Investment } \\
\text { (GFCP) in mining (Mill Tsh) }\end{array}$ & 2,502 & 3,085 & 18,737 & 92,975 & 118,808 \\
\hline 5 & $\begin{array}{l}\text { Share of investment in } \\
\text { mining in Total GFCF }\end{array}$ & 0.4 & 0.4 & 2.1 & 2.1 & 9.4 \\
\hline
\end{tabular}

Source: Bank of Tanzania: Economic and Operations report for the Year ended, June $30^{\text {th }} 2001$

\section{GFCF $=$ Gross Fixed Capital Formation at Factor Cost}

The growth rate in terms of contribution, for example growth in investment in 1996 (mill 2,502) to $2000(118,808)$ narrates the growth in Tanzania in terms of growth fixed capital formation at factor cost. This mirrors economic gains and growth but the cost of environmental destruction or conservation is never linked to this... does this show reversible process of such destruction? There are environmental problems associated with mining for example a growing number of artisanal or small scale miners =, driven by poverty and search for alternative income earning opportunities. Economic reforms in Tanzania (1985-1995), has witnessed movements of large numbers of people into the mining areas for example Rwangasa, and Matobe Biharamulo... what is the total economic values of environment? Positively, what are economic instruments which in addition needed for Tanzania to encourage Tanzanians to preserve environmental resources while generate funds for development? Think about the concept of economics against environmental degradation, in the context of tourism. (Foundations and endowments) need to be considered.

Global economy is creating profound and substantial changes for organization and industries throughout the world. These changes make it necessary for business forms or institutions to select strategies not only to fulfill their core objectives but also to keep attention on environmental issues for sustainable development for all stakeholders surviving...it is not only economics... John Keynes once said, " the greatest difficulty in the world is not or people to accepts new ideas, but to make them forget about the old ideas"...traditions in Tanzanian societies have been influencing the environmental content in polarized thought that environmental usage should be maximized to attain economic wealth (see table 1 above). Ornamental usage of minerals won't make a man survive; the cost associated with the environmental degradation cannot be easily estimated, though Tanzania has been adding values from 1996 (38,511 million) to 2000 (99, 519 million) Tsh at current factor.

Investment focusing at fixed capital formation at factor cost has been rising (focusing on motivation to use, not to conserve the environment) from $1996(2,502)$ to 2000 (118, 808). Thinking on undestructive land, forest fauna, forests create sensible women to cook but also virtual effect of sizing water streams, rivers and rain making for their source of water. Production such as honey traditional medicine, timber and shadow cover against wind and water waves and so forth cannot be over emphasized.

\section{Ecological RATIONS: Estimated Population Density AND LAND USE}

2009

Kilimanjaro is one of critical areas not only in terms of infrastructural development but great awareness, knowledge and keen traditional level. Kilimanjaro hosts majority of tribes from all over Tanzania due to developmental networks, services and good climate needed by all. It is also a place where climatic change is very much observed between environmental usage vis-àvis developmental usages. Consider the following patterns in the context of Agro-climatic zones. (Table 2). The Kilimanjaro mountain accounts for about 6 percent of the region's land area.

Table 2:Kilimanjaro Ecological Sense Measured :Climatic Zones Utilities Post-millennium

\begin{tabular}{|c|l|c|c|c|c|}
\hline S/N & Agro-climatic Zone & $\begin{array}{c}\text { Above sea } \\
\text { Level }\end{array}$ & $\begin{array}{c}\text { Tempe } \\
\text { rature }\end{array}$ & Rainfall & $\begin{array}{c}\text { Population } \\
\text { Density }\end{array}$ \\
\hline 1 & Mt. Kilimanjaro & $1,800-5895 \mathrm{~m}$ & $-0-15^{\circ} \mathrm{C}$ & $>2000 \mathrm{~mm}$ & - \\
\hline 2 & $\begin{array}{l}\text { High land (fertile } \\
\text { volcanic zone) }\end{array}$ & $1,100-1800 \mathrm{~m}$ & $15-25^{\circ} \mathrm{C}$ & $1250-2000 \mathrm{~mm}$ & $650 / \mathrm{sq} \mathrm{km}$ \\
\hline 3 & $\begin{array}{l}\text { Intermediate zone } \\
\text { (moderate fertility) }\end{array}$ & $900-1100 \mathrm{~m}$ & $25-30^{\circ} \mathrm{C}$ & $800-1250 \mathrm{~mm}$ & $250 / \mathrm{sq} \mathrm{km}$ \\
\hline 4 & $\begin{array}{l}\text { Low land } \\
\text { (Somewhat fertile) }\end{array}$ & Below 900m & $>30^{\circ} \mathrm{C}$ & $700-900 \mathrm{~mm}$ & $50 / \mathrm{sq} \mathrm{km}$ \\
\hline
\end{tabular}

Source: Kilimanjaro Region Social-Economic Abstract, October 2009

Table 3Kilimanjaro Economic Sense

\begin{tabular}{|l|l|l|}
\hline 1 & Regional GDP (2000) & Par capital Income (2000) \\
\hline 2 & Tsh. 290, 517 & Tsh. 147, 205 \\
\hline 3 & Regional GDP (2008) & Par Capital Income (2008) \\
\hline 4 & Tsh. 1073, 422 & Tsh. 684, 059 \\
\hline
\end{tabular}

Source: Ibid, 2009 compiled by Msaki J.L (2010)

Agriculture is the largest sector of the regional economy, contributing more than 60 percent pf the regional GDP. About 56 percent of Adult population are engaged in 
agriculture (HBS, 2000/2001). Kilimanjaro though being seen as heaven by parts and tribes of Tanzania, but its natural environment could be destroyed by a heavy population activities without conscious regulations from people to government where there must be balanced between energy, agriculture and environment use. Kilimanjaro still enjoys the focus in Tanzania.

From table 2 and 3 one can be conscious on how the GDP and per capital income increases, density in terms of population also increases and the land does not increase but economic requirement increases... furl wood is still the most dependable source of energy for domestic use (about 90\%). Electricity supply through hydro-electric power has been 54 percent (out of 450 registered villages, 234 villages-equivalent to 54 percent). About 18 percent of total households are connected to the National grid. Balancing between developmental pace and environmental resource use is the key aspect of surviving not only in Tanzania, but also in the world. Kilimanjaro has been taken as a case to emulate from all socialeconomic means. Life depends very much on people's relationship with the environment. Statistics shows that the number pf charcoal bags in markets is increasing every year, threating the survival of forests and natural resources in Tanzania ... According to the Daily News September 2008, $9^{\text {th }}$, Mr. Msiba was quoted saying that, " gas is the only savior that could rid urban dwellers out of charcoal uses." (remember that's just Kilimanjaro, 2008 Charcoal usage was 90 percent) ... the 15 litres of gas used to be sold 27, 000 Tsh in 2007 but in 2008 September the price of the same volume went to $32,000 \mathrm{Tsh}$ and the price had reached 48,000 Tsh currently, for the same capacity. In 2008 one sack of charcoal is sold for between 20, 000 Tsh. To 30, 000 Tsh ... What should be done in comparison? There is an economic suspense and a need to drive efforts in combating economic and environment degradation (environmental change brings social and economic negatives)

Think on the replacement from negative 1, where income generation assigned to growth of the group (population) therefore attitude change from greedy wealth creation to environmental conservation first towards wealth creation ... Mathematically, therefore

\section{EQUATION 1 TO BE CHANGED (PROPORTIONAL WISE): AT THE UNIT LEVEL}

$\mathrm{Yg}=W 1 \mathrm{~g} 1+\mathrm{w} 2 \mathrm{~g} 2 \ldots$ Wngn $\ldots \ldots \ldots \ldots \ldots \ldots \ldots \ldots \ldots \ldots \ldots$

$\mathrm{g} 1=$ the rate of growth of income of group 1

W1 = is welfare weight assigned to the growth of group into income

From income level, environment can be with the limit as one of the influence in poverty:

Consider:

(a) Upper poverty line: (US \$ 370) _ _ (a) UL

Growth interms of environmental protection

(as opposed to poverty creation)

gx (b) lower poverty line: (US \$ 275)

(b) LL

What is the condition in Tanzania currently? (GE1/GE2)

$\mathrm{Gx}=$ environmental protection - (extended) in lower-limit (LL) and upper-limit (UL). Therefore a replaced equation becomes:

$\mathrm{Yg}=\mathrm{w} 1 \mathrm{gx} 1=\operatorname{weg} X 2+\ldots \ldots \ldots . . w n g x n \ldots \ldots \ldots \ldots \ldots . .2$

A balanced feature becomes: considering a balanced weigh age features between the rate of income growth and environmental protection ... equation 3 is created how?

Therefore: $\mathrm{Yg}=\mathrm{W} 1 \mathrm{gX} 1 / \mathrm{W} 1 \mathrm{~g} 1+\mathrm{W} 2 \mathrm{~g} \times 2 / \mathrm{W} 2 \mathrm{~g} 2+$

WngXn/Wngn ..................................................

Therefore $\mathrm{Yg}=\mathrm{gX} 1 / \mathrm{g} 1+\mathrm{gX} 2 / \mathrm{g} 2 \ldots \mathrm{gXn} / \mathrm{gn} \ldots \ldots .4$

$\mathrm{G}=$ the rate of growth

Xn Extention of environmental protection

$\mathrm{Gn}=$ growth rate in income

Source: Msaki J. L (2011)

Considering table 2 and 3 for Kilimanjaro (2000:2008) and the 10 percent charcoal utilization, focusing on what needs to be changed from equation 4 . yg being the rate of aggregate growth between environment and wealth as projected by Msaki J.L (2011) the rates can be associated to all variables and impacts from temperature rise to the rate of migration, for example shifting mechanisms from rural areas where agriculture is affected to urban searching for other occupation with higher income rise. (g1) ... one needs to re-define economic system to suit environmental system.

Managing problems need large extent valuation, storage and utilizing the knowledge background of not creation and recreation of knowledge on how create equation 4 (balanced nature between environmental protection and wealth growth). " ecological research is illustrating the fundamental stable and productive ecosystems (Perrings et al, 1995; Raven, 1990) The biodiversity sustains rural and urban of Tanzania livelihoods from medicinal resources to nutritional et cetera. Maintaining aan agro-ecology economics and production, needs a recreation of sharing (discussed, through Dr. Msaki's ratio (GE1/GE2) and equation 4 in terms of their growths (gxn/gn) ... Think on the case study by (Gomez et al, 1998), which highlights: " Amazonia is a region of about 7 million $\mathrm{km} 2$, spreading over 9 South American countries. It houses enormous biological diversity and unique cultural diversity. Amazon is a leading biodiversity centre in the world, as well as the home to about 400 indigenous people"

What can be learnt from the ration (gxn/gn) concerning the case and table 1 and 2? Modernization has enforced "development" in Amazonia, through colonization, road building, agricultural expansion, deforestation and extraction of natural resources...dismantling traditional values and practices "Tassi, 1992; highlights that biodiversity loss accelerates, whilst the ecological, social and cultural domain of the indigenous people become severely disrupted." From the the comparative analysis measurement could be done through Msaki's ratio which compares ecological growth (GE1) over economic growth (GE2). 


\section{A Bipolar Preference and Growth Utility Challenges Ratio (GE1/GE2)}

From equestion 4, gxn could be equatedto GE1 and gn be GE2 therefore the ratio in measurement gxn/gn as (GE1/GE2) in terms of outcomes, challenges and prospects is known as Dr. Msaki J/L ratio, which literaly compares enrichment (growths) in terms of economics and ecology viz; ecology (g)/ economy (g)

$r^{\circ}=$ Ecologyg $/$ Economyg $=$ GE1 $/$ GE2 $=$ gxn $/$ gn $\ldots . . .5$

The ratio can be utilized to measure which factor grows (enriched in comparison). Empirical calculation is seen in table 4 between Kilimanjaro and Tanzania perspective. Agriculture contributes 69.2 percent

(2000)

Table 4: Dr Msaki's Ratio $\left(r^{\circ}\right)$ Estimated in GDP and Par Capital Systems - Reflections

\begin{tabular}{|c|c|c|c|c|c|c|c|c|c|c|}
\hline \multirow[t]{3}{*}{ Period } & \multicolumn{4}{|c|}{ KILIMANJARO } & \multirow{3}{*}{$\begin{array}{l}\text { G1/G2= }{ }^{\circ} \\
\text { GDP }\end{array}$} & \multirow{3}{*}{$\begin{array}{l}\text { G1/G2= } \mathbf{r}^{\circ} \\
\text { ParCap }\end{array}$} & \multicolumn{4}{|c|}{ TANZANIA } \\
\hline & \multicolumn{2}{|l|}{ G1 } & \multicolumn{2}{|l|}{ G2 } & & & \multicolumn{2}{|l|}{ G1 } & \multicolumn{2}{|l|}{ G2 } \\
\hline & GDP & ParCap & GDP & ParCap & & & ParCap & GDP & GDP & ParCap \\
\hline & Area & Area & Income & Income & $r^{\circ}$ & $r^{\circ}$ & AREA & AREA & $\mathrm{r}^{\circ}$ & $\mathrm{r}^{\circ}$ \\
\hline 2000 & 13,209 & 9.6 & 290,517 & 147,205 & 0.045 & 6.52 & $?$ & $?$ & $?$ & $?$ \\
\hline 2008 & 13,209 & 8.3 & 1073,433 & 684,059 & 0.012 & 1.21 & $?$ & $?$ & $?$ & $?$ \\
\hline DIRECTION & CONS & RED & INCR & INCR & RED & RED & $?$ & $?$ & $?$ & $?$ \\
\hline UNIT & KM2 & KM2 & Million Tshs & Tsh & $\mathrm{Mr}^{\circ}$ & $\mathrm{Mr}^{\circ}$ & $\mathrm{Mr}^{\circ}$ & $\mathrm{Mr}^{\circ}$ & $\mathrm{M} \mathrm{r}^{\circ}$ & $\mathrm{Mr}^{\circ}$ \\
\hline
\end{tabular}

CONS=Constant, RED=Reduction, $\mathrm{INCR}=$ Increase

Source: Msaki J.L (2011)

Land = constant: population changes: G1 Par capital $=$ (Area/population)

$\mathrm{G} 1=$ taken based on the size and distribution to the (changed population) but population $($ per capital $=$ par Cap) changes taken from the reflection:

2000 (est. 2002) census $=1,376,702$ Tanzania $=945,000 \mathrm{~km} 2$ 2008 (est. 2009) $\quad=1,590,950$ Tanzania Pop.

Table 5 Compositional Land Use in Kilimanjaro as related to ${ }^{\circ}$ (Msaki's Ratio)... Utility

Area $=$ constant : $13,209 \mathrm{Km} 2$

\begin{tabular}{|l|l|l|l|}
\hline S/N & $\begin{array}{l}\text { Land Use and } \\
\text { Distribution }\end{array}$ & Area (Sq. km) & $\begin{array}{l}\text { Percentage } \\
\text { use }\end{array}$ \\
\hline 1 & Arable Land & 6433 & 48.7 \\
\hline 2 & Game Reserve & 3051 & 23.1 \\
\hline 3 & Arid Land & 2018 & 15.3 \\
\hline 4 & Forest & 1403 & 10.6 \\
\hline 5 & Water & 304 & 2.3 \\
\hline 6 & Total & 13,209 & 100 \\
\hline
\end{tabular}

Source: www.kilimanjaro.go.tz (October 2009)

From the figures in table 4 , the value of $\mathrm{r} 0$ may change due to the rate of inflation and exchange rate (measured in monetary value) table 4 reflects more on Kilimanjaro... much could be done in terms of Tanzania as well. The direction from 2000 to 2008 (6 years) shows directions, as the land remains the same to support the use from ecosystem and production from human beings. To the side of income GDP there is an increase in million, but per capital (area) becomes smaller in respect to the increasing heavy load and utility from population growth and density within Kilimanjaro.

It is also enhanced that the ratio within land utility in terms of percentage usage takes arable land to be 48.7 National statistics shows 85 percent of Tanzania population are employed in the agricultural sector (dependency).
From the ration $\mathrm{r} 0$, where equation 5 is fixed on gxn/gn gxn should be extended to carry the extent of sustainable usage of land in Kilimanjaro, for example to the extent of 100 percent by redistribution of usage ad population density. It is also pathetic that the ratio r0 keeps on reduced promotes economics than sustainable development... what can then be done? The population grows ... but the population should note that carrying for eco-system will sustainably improve the climate and symbiotic supporting mechanisms. The economy should be support the ecology, as the input.

Therefore:

$\mathrm{r}^{\circ}=$ Output $/$ input=GE1/GE2=Ecology $(\mathrm{g}) /$ Economy $(\mathrm{g})=$

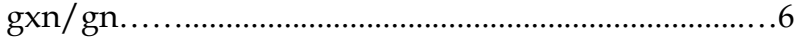

Charles Lamb, says, "the measure of choosing well is whether a man likes what he has chosen"... what is owned by the future ( $\mathrm{r} 0$ ) should be chosen by the action of man in the world, where a macroeconomic phenomenon us associated with the growth theory or efficiency f real economy ... productivity from equation 6 takes $r^{\circ}=$ output/input but this could be extended to all variables; GE1 =output1/input1 : GE2 =output 2/input2 Therefore; formula

GEQ/GE $=$ output1 $/$ input1 $=$ gxn $/$ gn $=r^{\circ} \ldots \ldots \ldots \ldots . .7$ Output2/input2

Articulation of ratio $r^{\circ}$ (Dr. Msaki J.L ratio) tries to settle proportionally in terms of efficiency, equity, growth and stability to be shared between economics usage and ecological enhancement...this needs "Nosnibor Effect" means all in r0 should be based on specific area and researchable variable analysis... where growth should be balanced between ecology and economics. Why is this important? Environment and climate reflect our lives and future surviving ... sustainable development.

Msaki's ratio promotes the idea of balancing utility in 
terms of output-input relationship...from equation 7 . Therefore the nature acts as we act upon it (GE1/GE2). The daily News on August 12 $12^{\text {th }} 2010$, p. 16 emphasizes on the ration $r^{\circ}$ in terms of global warming. Global warming is cutting rice yields in many parts of Asia, with more declines to come $(\mathrm{g})$. Yields have fallen by $10-20$ percent over the last 25 years in some locations. The research based on USA Scientist studied records from 227 forms in 6 important rice-producing countries such as Thailand, Vietnam, India and China... How should the world (GE1) feed its growing economy and population (GE2)? Much needs to be balanced through imbalances, for example Tanzanians need job opportunities, economic prospects and prosperity, less corrupt environment, peace and tranquility, political and religious tolerance...what else? All these need output/input balance $\left(r^{\circ}\right)$

Current ongoing researches on Agro-product must be willing secure people on surviving, providing sustainable food security and protect planet not to serve corporate interests (GE2). According to Business Standards of $21^{\text {st }}$ $27^{\text {th }}$ July 2009, Tanzania should be ready to reap natural gas... how; "one Kilogram of natural gas is equal to 1.5 litres of petrol, therefore if a plant is established, it can fill 20 cars per hour". This is where environment should be used to change people's lives as well. Until 2009, Tanzania managed to save more than 1.4 trillion Tsh as a result of using gas in generating electricity... according to $r^{\circ}$, it is real fundamental to enhance and propel what it takes to achieve poverty reduction, hunger reduction and increase economic stability in Tanzania without forgetting fundamental rights of the environment to be supported not exploited, but protected. Consider inflationary axe in Africa, where there is soaring food and fuel prices... these can escalate threats to growth, employment, good governance, peace and security. Increased climate volatility expected to worsen poverty vulnerability in Tanzania and elsewhere. Think on biofuels vis-à-vis food security. Where is r0? Pschorn Strauss was quoted by the Daily News of November 6 ${ }^{\text {th }} 2011$, p.13 that, "The biofuel industry has managed to develop mechanisms and agreements that will allow them to legitimately exploit the environment and people for financial gain"... In Africa, are we turning food fuel on hungry continent?

\section{StRATEGIC ENVIRONMENTAL ASSESSMENT AND THE ECONOMIC POWER}

Quoting Robert M. Solow, a Nobel Laureate in Economics, in his paper presented as the $8^{\text {th }} \mathrm{J}$. Seward Johnson Lecture to the Marine Policy Centre, Woods Hole oceanographic Institution, on the $14^{\text {th }}$ June 1991 he says, "Sustainability is about our obligation to the future". It is something moral obligation that we are supposed to have for first step towards answering a strategic question such as: should we torture our greedy module for the benefit of the next generation? Are we enjoying because the past generation were not greedy with higher $r^{\circ}$-ratio? (GE1/GE2). The debate on how to trade off between
Ecology (GE1) and economics (GE2) takes it to the bipolar parts of opinions with an outcome and prospects of Msaki's ratio, $\left(\mathrm{GE} 1 / \mathrm{Ge} 2=r^{\circ}=\right.$ Dr. Msaki J.L ratio)

The economy of Tanzania is dominated by the power of influencing GE1 (viz agriculture that dominates 47 percent of its GDP and sustains a curve of 85 percent). Accounting for less than 10 percent of GDP, her industrial sector is one of the smallest in Africa...Think of growth (g) in the name of industrialization, (heavy industries) and ecological need (GE1) based on sustainable development expressed in equation 4 and equation 8 of the literature.

From equation derivation of the ration $r^{\circ}$ and the need of majority population (45 million est.) towards 85 percent of surviving agri-sector. To quote a comment form Gert Nyberg, scientist from Sweden University... "Soil fertility depletion on small is food production is Sub-Saharan Africa; for which rapid population growth and the breakdown of traditional agricultural practices are some of the main reasons. Soil fertility may be improved by short-term follow planted with selected tree species or the use of green manure in biomass transfer systems, which are realistic alternative for small scale farmers who cannot afford to buy organic fertilizers"... Basically management of such information from scientific assessment and researches is a needful mechanism not only to understand the philosophy of nature vis-à-vis economic gains, but also transforming the culture on how people should act on the nature for long term features of positive enriched generations and survival. It is also very true from philosophical point of view that ecology and economics facts are always straight forward as they seem... Are poor farmers caught in viscous circle in their management of natural resources (GE1); is there core relationship between pverty and environmental degradation (GE2)? What is the core source, focus on degradation (GE2)? from the long debate to re-establish the concept of $\mathrm{r} 0$, the following conceptual figure (fig 1) diagram was established to balance the $\left(r^{\circ}\right)$ as GE1/GE2.

Not everything of importance in human circles (Tanzania) concerns money... after all the nature of Tanzania societies was not capitalistic rather was socialistic (balanced attitude) one can argue through $r^{\circ}$ mechanics that; does changing in attitude and personality of the nature disturb a balancing ratio $\left(r^{\circ}\right)$ as proposed by Dr. Msaki J.L (2011) ? being market oriented economy means heavy articulation of variable (GE2) that is economic attitude than social ecological attitude (GE1) where sustainable economic needs to be re-applied (fig 1).

What happened in Bhopal Carbide Accident in India, was a denial for balanced $\left(r^{\circ}\right)$ where GE2 appears to support the minority economic gains, without considering the majority sustainability, in safety (GE1)... the experience did not cover the explanation in figure 1. From the establishment of Msaki's ratio $\left(r^{\circ}\right)$, Tanzania can frame 2 basic questions, following the figure 1 roots articulation between GE1 and GE2 with equitably and rationality in environmental sustainable philosophy. 
Implementation Cycle of Msaki's Ration ( $r^{\circ}$ ) ROOT I AND ROOT II

A

\section{ROOT 1 \\ ROOT II}

Both root I and root II takes a society to required benefits of balancing their economic needs vis-à-vis ecological survival. A comparison study in establishing Dr. Msaki's ratio between Kilimanjaro region and Tanzania (a nation) in table 4 suggest a single dimension of the present discussion (debate). A distinctive speed of operation takes between the decision to use root I or root II, to reach the goal of gxn/gn = GE1/GE2. The best from philosophy of Dr. Msaki's ratio articulation form fig 1, is therefore; " the best environment practice (balanced GE1/GE2) and policy is that one which focuses on an efficiently functioning market equation ( equation 7 and 8), guided by enlighted institutional and social protections (fig. 1 Root I and II) where all stakeholders are involved critically with interest and influence (equation 4). This is the significance of any Nation economic and social policies, in tailoring cohesive and positive economic outcome with undeniable and step forward from what should be the level of living standard by considering a long term effects on ecological platforms." ...( gxn/gn...GE1/GE2 ... $\left.r^{\circ}\right)$. A case of Kilimanjaro - Tanzania in Africa has been taken, in table 4, whereby it has been categorized in 4 zones in terms of agro-climatic zone, altitude, temperature, rainfall and population density.

From equation 1 of the literature, who sets the limits (UL) vis-à-vis (LL), US \$ 370 and us \$ 275 respectively? The present liture therefore focuses on the provision of an opportunity to apply economic theory and empirical methods and data, to understand some urgent issues in Tanzania (GE1) in respect to gloabal requirement (GE2). The challenge presently for Tanzania economy ecology balance in the namen of strategies and policies are:

Are poor farmers (85 percent of population) in
Tanzania, caught in viscous circle in terms of their
unbalanced management of environment and
ecosystems (GE1); Is there core relationship between
poverty and environmental degradation? A of $r^{\circ}$
articulation (table 4)

Question A: (Msaki J.L. 2011)

What counts on the cross regional disparities (diversities) in Tanzania? Considering wealthecological richness, what counts on sustainable cross country growth diversities over time on regions of Tanzania? ( equation1, consider calculation on empirical statistics from table 4 )

Question B: (Msaki J.L 2010/2011)

Most people in Tanzania including our political leaders do not seem to feel any sense of urgency or danger about climate change, how should we influence the re-balancing ratio $\left(r^{\circ}\right)$ ? where economic growth need to be achieved (GE2) as well as ecosystem positive enrichment and protection (GE1)? The problem of deforestation is huge in Tanzania where 80 percent is due to increase farm land to feed growing population (currently population in Tanzania is approximately 45 million growing at the rate of 16 percent annually. In Africa for example, shifting cultivation is still a common practice that also involves the use of fire to prepare and clear virgin lands for agriculture and agriculture employs 85 percent of population (45 percent of GDP).

One of the solutions could be seem to be boosting agricultural productivity in Tanzania, so that les demand to covert forests into farm lands. Farmlands is not the only stress but population makes and add on urbanization through building settlement should we reduce population? There is a significance of $\left(r^{\circ}\right)$ study on both economic perspective and ecological perspective as Tanzania needs both (GE1) and (GE2).

According to FAO statistics, "Global forest occupies only 4 billion hectares, covering 30 percent of the world's land. From 1990 to 2005, the world lost 3 percent of its total forest" ... Therefore 30-3=27 (1990 - 2005) but the rate at which we the forests are lost was not much emphasized, but according to Dr. Msaki's ratio $r^{\circ}$, rates in finance and economics are more significant than quantity as the flow determines the quantity... (losing rate and gaining rate) ... (r0) Africa accounts for 16 percent of the world forests but during the same period it lost 9 percent of its forests. Therefore 16-9 percent $=7$ percent $\ldots$.. higher rate of forests being lost in Africa. A great and simplistic comparison could be done through the $\left(r^{\circ}\right)$ viz; table 1 framework and fig 1 articulation.

According to the Guardian, 2007, Nov., 9 $9^{\text {th }}$ between 19902005, Tanzania lost an average of annual 412, 300 hectares of forest per year. Which is an average of annual deforestation rate of 0.99 percent. The country's forest covers stands at 39.9 percent of the total land area, which is equivalent to $35,257,000$ hctares. Who needs to act on these dynamics? One can as well remember that during 1990 's that is when Tanzania was in the process of transforming intensively into market boost (GE2) competitively and less to boost (GE1) . Tanzania should re-visit technically its $\left(r^{\circ}\right)$ as suggested by Dr. Msaki J.L, where sustainable development to protect the livelihood is crucial... create the ecology to create the economy.

\section{ESTABLISHED CONCLUSION FROM THE BI-POLAR Growth DissonanCE ( $\left.r^{\circ}\right)$}

Can we predict on flood, cost, people lives... damages on the current floods? The ration $r^{\circ}$ is not for the government of Tanzania only to re-think but to an individual Tanzanian including Dr. Msaki who profound the GE1/GE2 ... in whatever we do progressively to achieve our economic gains. Energy sever charcoal cooking stoves could reduce pressure from forest, natural gas et cetera. Solution from within and from outside should be the 
focus. Curbing deforestation for example must originate from within Tanzanians and from the world as we are all users of GE2, through exports and import paradigm for example. This will enhance the process of re-balancing environmental problems such as global warming...introduction of environmental friendly policies and technologies is crucial. Institutions and structures on climatic -economy observation is crucial for Tanzania's future ecosystem. Think on Tanzania Revenue Authority, and other institutions which regulate our behavior can ne attained through the process of linking and regulating between earth usage (E1) vis-à-vis economic gains (E2)... recreation of $\left(r^{\circ}\right)$ to suit or future our future generations...think on food versus biofuels debate... what should be our $\left(r^{\circ}\right)$ ?

There is so much in the agro-fuel promise such as jatropha cultivation...yet to be materialize, should we make energy or cultivate food for our survival? Which percentage of population is engaged on this in Tanzania? Tanzanians need to accommodate successful developmental needs within this customary fframeworks for their survival as they know much better their economic needs (E2) and surviving environment (E1). Draught and floods are two major extreme climate events impacting Tanzania today. In May 2006, floods seriously affected Kilimanjaro region, leaving over 19,000 people homeless and 14.6 square kilometer of crop destroyed. According to the Guardian, March $3^{\text {rd }} 2011$ p.11 using the 2008 GDP figure as an example a cost of 1-2 percent of GDP in Tanzania is affected by climate change that amounts to Tshs 250 billion - 500 billion lost, equivalent to about half of what the government plans to spend on primary education $(2008 / 09)$. Through $\left(r^{\circ}\right)$, climate and environmental changes covers both economics and environment.

\section{REFERENCES}

Anthon G, Sociology, Revised and Updated by Philip Sutton, Polity Press, USA, 2009, pp 170 - 171

Msaki J.L (2010) Insearch of New Equlibrium: GrowthEnvironment Bi-polar Preferences and Utility Challenges: A paper presented to Old Moshi technical Support Students (Secondary School ) Unplushed Work

Perrings, C. et al, Biodiversity Loss: Economic and Ecological issues, Cambridge University Prss UK, 1995

Richard Watchman, Observer 9th December 2007

The Business Standard, July 21 ${ }^{\text {st }}-27^{\text {th }}, 2009$

The Daily News November, $6^{\text {th }} 2011$, p.13

The Daily News, September 2008, $9^{\text {th }}$

The Guardian of November 9th 2007, p. 12

The New Scientist, 1 October 2003

The United Nations-UNDP Report 2002

Tossi G (ed). 1992, Naufragos del Mar Verde: La Resistencia de los Huaorani a una integracion impuesta: Abya-Yala Confeniae. Quito, Equador

www.kilimanjaro.go.tz

www.theglogabaleducationproject.org/earth/human-

conditions.php (accessed, January 2008) 